\title{
Outsourcing in the brain: do neurons depend on cholesterol delivery by astrocytes?
}

\author{
Frank W. Pfrieger
}

\begin{abstract}
Summary
Brain function depends on the cooperation between highly specialized cells. Neurons generate electrical signals and glial cells provide structural and metabolic support. Here, I propose a new kind of job-sharing between neurons and astrocytes. Recent studies on primary cultures of highly purified neurons from the rodent central nervous system (CNS) suggest that, during development, neurons reduce or even abandon cholesterol synthesis to save energy and import cholesterol from astrocytes via lipoproteins. The cholesterol shuttle may be restricted to compartments distant from the soma including synapses and may be regulated by electrical activity. Testing these hypotheses will help to improve our still insufficient understanding of brain cholesterol metabolism and its role in neurodegeneration.
\end{abstract}

BioEssays 25: 72-78, 2003. (C) 2002 Wiley Periodicals, Inc.

\section{Introduction}

Specialization and cooperation of cells are fundamental principles of operation in tissues and organs of multicellular organisms. The nervous system provides an outstanding example for cellular differentiation and share-of-labor: neurons specialize in the generation and exchange of electrical signals, whereas different types of glial cells provide structural and metabolic support for the neuronal network. ${ }^{(1)}$ Notably,

Max-Planck/CNRS Group, UPR2356, Centre de Neurochimie, Strasbourg, France. E-mail: fw-pfrieger@gmx.de

Funding agencies: Centre Nationale de Recherche Scientifique, MaxPlanck-Gesellschaft, Fondation Pour La Recherche Medicale, the Fondation Electricite de France, Ara Parseghian Medical Research Foundation and Deutsche Forschungsgemeinschaft.

DOI 10.1002/bies.10195

Published online in Wiley InterScience (www.interscience.wiley.com).

Abbreviations: ABCA1, ATP binding cassette A1; ApoA1, apolipoprotein $A 1 ; A p o D$, apolipoprotein $D ; A p o E$, apolipoprotein $E$; ATP, adenosine triphosphate; CNS, central nervous system; CSF, cerebrospinal fluid; HDL, high-density lipoprotein; HMG-CoA, 3hydroxy-3-methyl-glutaryl coenzyme a; NADPH, nicotinamide adenine dinucleotide phosphate (reduced form); NPC1, Niemann Pick C Protein 1; RGCs, retinal ganglion cells; SREBP, sterol regulatory element binding protein. neurons and glia also cooperate during brain development by controlling mutually their proliferation, survival and differentiation. ${ }^{(2)}$

Here, I propose a new type of neuron-glia interaction in the CNS. My hypothesis states that, after differentiation of astrocytes, neurons reduce their cholesterol synthesis and rely constitutively on cholesterol delivery by astrocytes via lipoproteins. In the following paragraphs, I will present experimental evidence for this hypothesis and suggest possible ways to test it. Furthermore, I will highlight still unanswered questions concerning glial and neuronal metabolism and describe implications for neurodegenerative diseases. The idea of an obligatory cholesterol shuttle from astrocytes to neurons goes beyond previous proposals that non-neuronal cells including astrocytes participate in the recycling of cholesterol after injury in the peripheral ${ }^{(3)}$ or central nervous system. ${ }^{(4)}$ Summaries on the metabolism of cholesterol, ${ }^{(5,6)}$ lipoproteins $^{(4,7)}$ and neurosteroids ${ }^{(8,9)}$ in the brain can be found in recent reviews.

\section{Experimental evidence for neuronal dependence on glia-derived cholesterol}

The hypothesis outlined above has been provoked by a series of studies that aimed originally to define the role of glial cells in synapse development. This glial function is indicated by the fact that throughout the CNS, most synapses develop after the differentiation of astrocytes. ${ }^{(10)}$ To study a possible influence of glia on synapses, Pfrieger and Barres ${ }^{(11)}$ separated neurons from glial cells and studied their development in isolation. This reductionist approach became possible with the establishment of methods to highly purify retinal ganglion cells (RGCs) from postnatal rats and to culture them for several weeks under defined conditions. ${ }^{(12)}$ Pfrieger \& Barres ${ }^{(11)}$ observed that neurons form glutamatergic synapses under these conditions, but that a soluble factor secreted by macroglial cells strongly increases the level of spontaneous synaptic activity without affecting neuronal growth or survival. Subsequent studies showed that this effect was due to a strong increase in the number and the efficacy of synapses. ${ }^{(13,14)}$ Finally, Mauch et al. ${ }^{(15)}$ identified this synapse-promoting factor as cholesterol secreted by glial cells in apolipoprotein E- (ApoE-) containing lipoproteins. Their discovery suggests 
that RGCs depend on an external supply of cholesterol to form numerous and efficient synapses. ${ }^{(16-18)}$

Given the large number of studies on primary neuronal cultures, one may ask why this dependency has gone unnoticed. A possible answer is that the medium of conventional cultures contains cholesterol-rich lipoproteins due to the addition of serum or the presence of glial cells. Furthermore, most cultures are prepared from embryonic brain, whose neurons may not need external cholesterol. Further support that cholesterol is a limiting factor for neurons comes from studies on conventional cultures prepared from fetal or newborn mammals. They showed that addition of cholesterol promotes $^{(19)}$ and inhibition of cholesterol synthesis impairs neuronal survival and growth. ${ }^{(20-22)}$

\section{Astrocytes as cholesterol-producing factories}

It is well established that glial cells produce and secrete surplus cholesterol (Fig. 1). In vitro studies revealed that astrocytes synthesize two- to three-fold more cholesterol than neurons or fibroblasts ${ }^{(23)}$ and secrete lipoprotein particles, which serve as cholesterol carriers, into the culture medium. ${ }^{(24,25)}$ Notably, DeMattos and colleagues showed that astrocytes secrete lipoproteins in vivo. They detected human
ApoE in the cerebrospinal fluid (CSF) of transgenic mice that express human ApoE in a subclass of astrocytes. ${ }^{(26)}$ So far, however, it is less clear, whether and how the release of lipoproteins from astrocytes is regulated. Removal of lipoproteins from culture medium causes upregulation of cholesterol synthesis in different glial culture preparations, ${ }^{(27,28)}$ but it is not known whether this also affects lipoprotein release. Interestingly, secretion of $A p o E$ and $A p o D$ is differentially regulated in cultured astrocytes ${ }^{(29)}$ suggesting that astrocytes secrete different types of lipoproteins depending on the extracellular lipid milieu.

So far, it has remained enigmatic why astrocytes express specific apolipoproteins and why they secrete cholesterol-rich lipoprotein particles. ${ }^{(4)}$ The idea that neurons depend on gliaderived cholesterol may provide an explanation.

\section{Cholesterol metabolism in neurons}

The finding that cultured CNS neurons depend on an external cholesterol supply raises several questions concerning the neuronal cholesterol metabolism, which I will discuss in the following paragraphs. It will become apparent that, despite the wealth of information about cholesterol, surprisingly little is known about how neurons handle this essential membrane component.

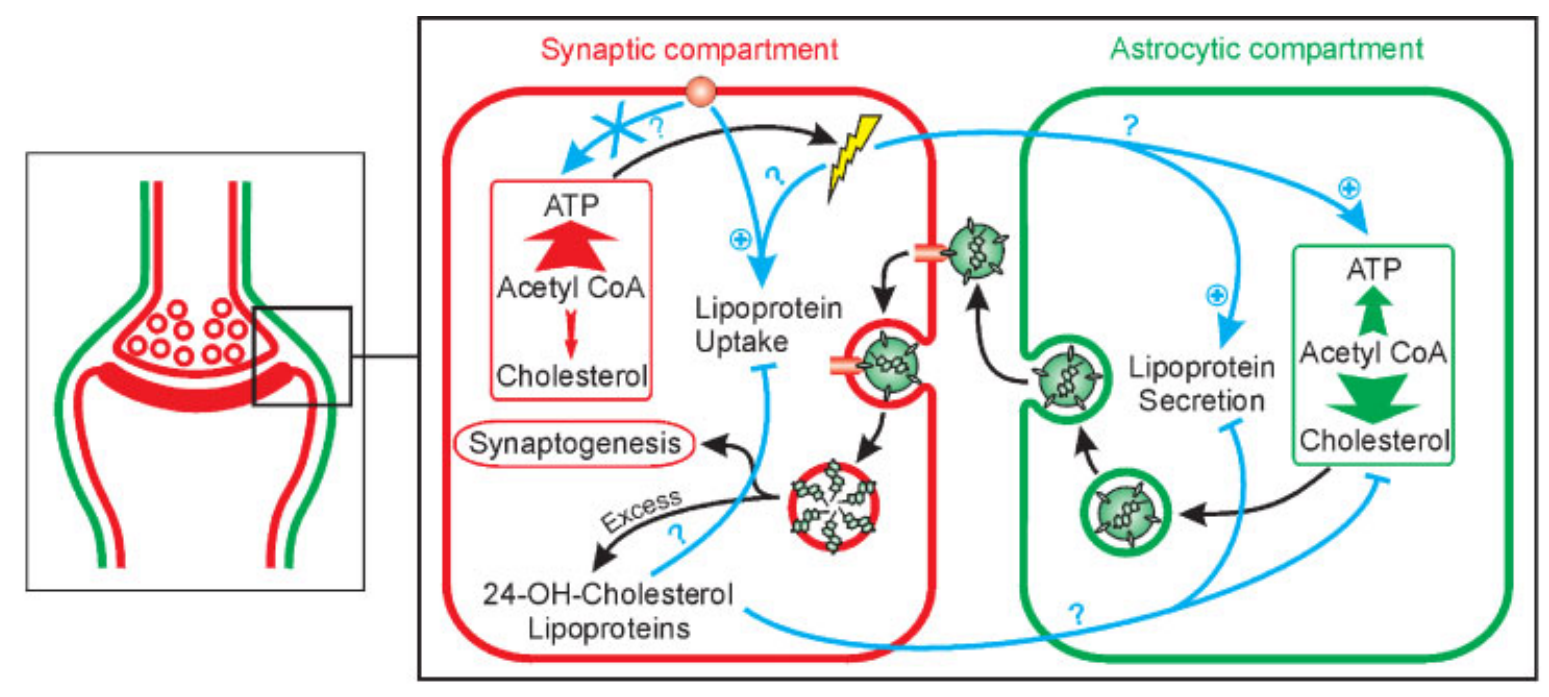

$\omega^{00}$ Astrocytic cholesterol $\triangle$ ApoE $=$ Lipoprotein receptor $\$$ Electrical activity $\bigcirc$ Sterol-sensing element

Figure 1. The cholesterol shuttle from astrocytes to neurons. The diagram illustrates the hypothetical cholesterol shuttle from astrocytes to synapses and possible regulatory mechanisms. Astrocytes release lipoproteins in the vicinity of synapses, where they are taken up by receptors on presynaptic terminals and postsynaptic spines. The sterol-sensing pathway in neurons enhances lipoprotein receptor density and may induce release of lipoproteins from astrocytes, possibly without affecting cholesterol synthesis in neurons. Electrical activity may raise the density of lipoprotein receptors in neurons or boost cholesterol synthesis and lipoprotein release from nearby astrocytes to allow for plasticity-induced synaptogenesis. Neurons dispose of excess cholesterol by releasing oxysterol or lipoprotein particles, which in turn may feed back on cholesterol synthesis and release from astrocytes. 


\section{Do neurons synthesize cholesterol?}

Although this question appears trivial, it is hard to answer. All cholesterol contained in the brain is probably synthesized locally rather than imported from the blood. ${ }^{(5,30,31)}$ So far, however, it is not known whether neurons contribute to the brain pool of cholesterol.

My hypothesis postulates that neurons switch from production during embryonic stage to outsourcing after birth. Previous studies demonstrated that CNS neurons from embryonic brain ${ }^{23,32)}$ and sympathetic neurons from newborn rats $^{(20,33)}$ synthesize cholesterol in vitro. Little is known about cholesterol synthesis in older neurons. Radioactively labeled cholesterol appeared in axons of RGCs after intraocular injection of tritiated acetate in adult rats, ${ }^{(34)}$ but it is not clear whether the sterol was synthesized by glia or neurons. Several studies detected mRNA encoding cholesterol-producing enzymes in the adult brain $^{(35,36)}$ and revealed developmental changes in their expression levels, ${ }^{(37,38)}$ but they did not examine whether the enzymes are expressed by neurons. Swanson et al. ${ }^{(39)}$ showed expression of 3-hydroxy-3-methylglutaryl coenzyme a (HMG-CoA) synthase in hippocampal and sensory neurons of young rabbits, but did not study its expression in adult animals. Notably, the presence of this enzyme is not sufficient to establish cholesterol synthesis, since it is also required for isoprenoid production. So far, it is not clear, whether neurons express enzymes that are specific for cholesterol synthesis. Future studies need to address this issue and the question whether the neuronal cholesterol metabolism changes during development.

\section{Why should neurons import rather} than synthesize cholesterol?

A possible reason could be the enormous logistical costs of sterol synthesis. Formation of the sterol molecule requires a whole battery of enzymes that are distributed in different subcellular organelles and consumes large amounts of energy substrates. Therefore, neurons, which specialize in the generation of electrical activity, may reduce or even abandon cholesterol synthesis. This may apply particularly to neuronal compartments like axon terminals and dendritic spines, which are distant from the soma (Fig. 1). They may import cholesterol rather than relying on local synthesis or intracellular transport from the soma. In agreement with this, Vance and coworkers showed that distal axons of sympathetic neurons cannot produce cholesterol. $^{(20,33)}$ The idea that neurons outsource cholesterol synthesis to glia is supported by other examples of metabolic cooperation between these cells. ${ }^{(40-42)}$ Future studies will show whether cholesterol synthesis and energy metabolism are coupled. To accomplish this, it may be timely, to dissect these interactions by a system analysis approach using quantitative computational models that integrate different metabolic pathways in neuronal and glial compartments. ${ }^{(43)}$ This may help to formulate testable hypotheses about metabolic job-sharing and to predict changes in metabolite levels due to pathological conditions or pharmacological interference.

How and where do neurons take up cholesterol? In general, cellular uptake of cholesterol requires lipoprotein binding to receptors in the plasma membrane, endocytosis of ligand-receptor complexes and their processing in the endosomal-lysosomal pathway ${ }^{(6,44,45)}$ (Fig. 1). Numerous studies have shown that neurons express different members of the lipoprotein receptor family. ${ }^{(46,47)}$ As stated above, lipoprotein uptake may occur preferentially in presynaptic terminals and dendritic spines, which are unable to synthesize cholesterol (Fig. 1). Lipoprotein receptors are present on dendrites $^{(48,49)}$ and axons and dendrites contain endosomallysosomal organelles ${ }^{(50)}$ indicating that these compartments could process lipoproteins. Direct evidence that neuronal processes can handle lipoproteins comes from studies on neuron-like pheochromocytoma cells ${ }^{(51)}$ and on sympathetic neurons. ${ }^{(20)}$ I should mention that cells can also acquire cholesterol by an alternative, endocytosis-independent pathway that involves specific lipoprotein receptors and direct transfer of cholesterylester from high-density lipoproteins to the plasma membrane. ${ }^{(6)}$ Future studies will show which types of lipoprotein receptors mediate the cholesterol import in neurons and where they are localized.

\section{Do all neurons depend on cholesterol import?}

The structural and functional specialization of brain regions suggest that their cholesterol metabolism is not uniform. ${ }^{(30)}$ Thus, some neurons may depend entirely on an external cholesterol supply, whereas others may be autonomous. Support for this idea comes from studies revealing regional and cell-specific differences in the cholesterol content ${ }^{(52)}$ and in the expression profile of cholesterol synthesizing enzymes, ${ }^{(35,36)}$ sterol-sensing components, ${ }^{(53)}$ intracellular transporters $^{(54)}$ and lipoprotein receptors. ${ }^{(49,55)}$ Within the hippocampus, mRNA encoding the HMG-CoA synthase and low-density lipoprotein receptor is restricted to the pyramidal cell layer. ${ }^{(39)}$ It will be interesting to see whether the neuronal dependence on glia-derived cholesterol varies in a regionspecific manner as well.

\section{Regulation of the cholesterol shuttle}

The idea that neurons depend on an import of cholesterol raises the question how this exchange is regulated. Obviously, neurons like all other cells must strictly control their cholesterol content, since too much or too little of this component is lethal. ${ }^{(56)}$ In general, cells maintain the cholesterol level by an intriguing mechanism that involves sterol-sensing elements in membranes and transcription factors controling the expression of cholesterol synthesizing enzymes and lipoprotein

\section{BioEssays 25.1}


receptors $^{(57)}$ (Fig. 1). Surprisingly, it is not known whether this pathway is implemented in neurons. Ong et al. showed recently that hippocampal and cortical neurons express a key element of this pathway called sterol regulatory element binding protein (SREBP), ${ }^{(53)}$ but its function in neurons remains to be established.

\section{Does synaptic plasticity alter} cholesterol homeostasis?

The link between cholesterol and synaptogenesis suggests that neurons require external cholesterol for activitydependent structural changes. This idea provokes the exciting question whether electrical activity influences cholesterol homeostasis. Two non-exclusive scenarios can be envisioned. First, electrical activity may activate the cholesterolregulating pathway in neurons and increase selectively their capacity for lipoprotein uptake without activating cholesterol synthesis. Second, electrical activity may enhance cholesterol production and lipoprotein release in astrocytes (Fig. 1). There is good evidence that astrocytes can sense the level of synaptic activity by neurotransmitter receptors. ${ }^{(58)}$ Interestingly, transporter-mediated glutamate uptake in astrocytes stimulates glycolysis thus coupling synaptic activity and energy metabolism. ${ }^{(40,41)}$ This pathway may also influence cholesterol synthesis and lipoprotein release in astrocytes thereby helping neurons to cope with the activityinduced need for cholesterol. As a first step to determine the validity of these considerations, it should be examined whether structural plasticity leads to a local cholesterol deficit in neurons and induces lipoprotein transfer from nearby astrocytes.

If electrical activity modulates cholesterol homeostasis in neurons, one would expect that an impairment of cholesterol synthesis or lipoprotein transport diminishes synaptic plasticity, and possibly learning and memory. Pharmacological inhibition of HMG-CoA reductase eliminated the late phase of long-term potentiation in hippocampal slices, ${ }^{(59)}$ but it remains unclear whether this is due to reduced synthesis of isoprenoids or of cholesterol. Removal of cholesterol from hippocampal slices by cyclodextrin abolished tetanic potentiation of evoked synaptic responses, ${ }^{(60)}$ but this effect may have been due to changes in the biophysical properties of the plasma membrane. A recent study revealed that eyeblink conditioning, a form of associative learning that involves synaptogenesis, ${ }^{(61)}$ is sensitive to cholesterol inhibitors. ${ }^{(62)}$ Together, these results call for more studies on the possible link between cholesterol homeostasis and synaptic plasticity.

\section{How do neurons get rid of excess cholesterol?}

If neurons import cholesterol from glia, they need to protect themselves from overload. This could be accomplished by the release of surplus cholesterol or by a feedback mechanism that reduces lipoprotein import (Fig. 1). In general, cells dispose of cholesterol via different pathways including ApoA1containing high-density lipoproteins. ${ }^{(5,6)}$ So far, it is not clear, whether neurons employ similar mechanisms. Neurons express the ABCA1 transporter, which transfers cholesterol to high-density lipoprotein (HDL) particles, ${ }^{(63)}$ and HDL-like particles containing apolipoprotein A1 (ApoA1) are present in CSF. However, ApoA1 is supposed to be synthesized outside the brain. ${ }^{(4)}$

An alternative pathway is suggested by recent evidence for a net flux of 24-hydroxy-cholesterol from brain to blood. ${ }^{(64)}$ The enzyme that synthesizes this cholesterol derivate, a specific isoform of cytochrome P450, is expressed by neurons but not by astrocytes or oligodendrocytes ${ }^{(65)}$ suggesting that neurons get rid of excess cholesterol by converting it to oxysterol (Fig. 1). In addition, the component may reduce cholesterol production and lipoprotein release in nearby astrocytes (Fig. 1). It is well known that oxysterols inhibit cholesterol synthesis in cultured cells. ${ }^{(56)}$ Interestingly, a recent paper showed that activation of the liver $X$ receptor, which binds oxysterols, leads to increase in cholesterol release from glial cells without affecting ApoE expression. ${ }^{(66)}$ This prompts the idea that neuron-derived oxysterols may induce the release of cholesterol from glial cells in specific lipoproteins that cannot be taken up by neurons thereby reducing their cholesterol intake.

Obviously, a whole battery of experiments is required to attack exciting questions such as how neurons regulate their sterol content, whether they signal their need for cholesterol to astrocytes and whether electrical activity influences cholesterol homeostasis.

\section{Do neurons need astrocyte-derived cholesterol in vivo?}

Among the questions that have been raised in this article, this is probably the most pressing. Unfortunately, the existing literature does not provide an answer. On the one hand, genetic or pharmacological elimination of cholesterol synthesis in mammals is teratogenic and causes massive CNS defects. ${ }^{(67-69)}$ On the other hand, mice deficient in ApoE show no major developmental defects in the CNS, ${ }^{(4,5,70)}$ although cultured astrocytes from $\mathrm{ApoE}^{-/-}$mice do not release cholesterol. ${ }^{(71)}$ Finally, mice lacking specific lipoprotein receptor subtypes either die during early development, ${ }^{(72,73)}$ show defects that are independent from lipoprotein uptake ${ }^{(74)}$ or develop normally. ${ }^{(47)}$ Evidently, these observations do not reveal whether neurons depend on glia-derived cholesterol. The fact that brain development proceeds normally in the absence of specific apolipoproteins or lipoprotein receptors may be due to activation of redundant pathways. Consequently, a rigorous test of the proposed shuttle hypothesis in vivo requires new animal models, where cholesterol synthesis or lipoprotein release can be modified in a celltype-specific and temporally controlled manner. The fact that 
animal species and strains differ in their cholesterol and lipoprotein metabolism ${ }^{(75)}$ cautions that the cholesterol shuttle needs to be studied on different genetic backgrounds.

\section{Implications for neurodegenerative diseases}

The idea that neurons depend constitutively on astrocytederived cholesterol postulates that any interference with cholesterol delivery leads to neurodegeneration. The cholesterol shuttle involves several steps, each of which may be perturbed by injury or disease. These include production and secretion of cholesterol-rich lipoproteins by astrocytes, intercellular lipoprotein transport and, finally, their uptake and processing by neurons. A deficit in cholesterol may first cause degeneration of synapses, axons and dendrites, which are unable to synthesize cholesterol, and then lead to cell death. The damage in specific brain areas may vary depending on the neuronal need for glia-derived cholesterol with some regions showing massive degeneration and others remaining largely unaffected.

In the following, I will illustrate consequences of these scenarios by three exemplary diseases. First, according to the shuttle hypothesis an impaired cholesterol production by astrocytes should lead to neurodegeneration. Smith-LemliOpitz/RSH syndrome (OMIM \#270400) is an autosomal recessive disorder affecting one in 20,000 to 40,000 births, which causes mental retardation and malformations in practically every tissue. The disease is caused by mutations in 7-dehydrocholesterol reductase, the enzyme that catalyzes the final step in cholesterol synthesis. ${ }^{(67,69,76)}$ It is possible that the enzyme is only present in astrocytes and that its inactivation causes neuronal damage indirectly by imparing cholesterol production by astrocytes. So far it is not clear, however, which cells in the brain express this enzyme.

Second, the shuttle hypothesis predicts that any interference with lipoprotein release, transport or uptake may cause neurodegeneration. Alzheimer's disease (OMIM \#104300), ${ }^{(77)}$ a devastating dementia whose late-onset form affects $50 \%$ of people above age 85 , may be caused, at least in part, by an impaired delivery of cholesterol from astrocytes to neurons. The notorious culprits, $\beta$-amyloid and the ApoE4 isoform, may lower the efficacy of lipoproteinmediated cholesterol transfer or disturb cholesterol homeostasis in neurons ${ }^{(78-81)}$ and glia. ${ }^{(82)}$ Possible links between cholesterol and Alzheimer's disease have been discussed previously. ${ }^{(6,83-86)}$

Third, the shuttle hypothesis predicts that an impaired neuronal ability to take up and process lipoproteins should cause degeneration. Support for this idea comes from studies on Niemann-Pick type C disease (OMIM \#257220). This autosomal recessive lysosomal storage disorder occurs in about one of 100,000 births and leads to progressive neurodegeneration and premature death. ${ }^{(87)}$ The defect has been traced to mutations in the Niemann-Pick protein $\mathrm{C} 1$
(NPC1), which is involved in intracellular processing of endocytotically acquired cholesterol. ${ }^{(88)}$ The fact that a defect in NPC1 causes loss of axons and dendrites and neuronal cell death ${ }^{(89,90)}$ provides strong support for the hypothesis that neurons in vivo depend on cholesterol from an external source. Interestingly, neurotrophins fail to activate trk receptors and to induce neurite outgrowth in cultured neurons with a defective NPC $1^{(91)}$ suggesting that external cholesterol is required to establish functional neurotrophin signaling pathways. ${ }^{\left({ }^{84}\right)}$ Finally, it would be interesting to know whether defective NPC1 also impairs cholesterol secretion by astrocytes, whose processes contain NPC1. ${ }^{(92)}$ NPC1 disruption induces cholesterol accumulation $^{(93,94)}$ and changes the apolipoprotein pattern ${ }^{(95)}$ in astrocytes.

Taken together, the cholesterol shuttle hypothesis may provide an explanation why disorders of cholesterol homeostasis cause neurodegeneration. Notably, it may also prompt studies on the role of cholesterol in neurodegenerative processes that have not been linked to this lipid. An important prerequisite to define connections between cholesterol and brain disorders will be the ability to monitor activity- or diseaseinduced changes in brain cholesterol. Since such changes are probably restricted to small regions and do not show in a global parameter like the CSF concentration, their detection may require new experimental approaches like "molecular imaging".(96)

\section{Conclusion}

In this article, I propose a new form of metabolic cooperation between neurons and astrocytes that allows neurons to specialize in electrical signaling. According to my hypothesis, neurons reduce or even abandon the expensive synthesis of cholesterol and import the component from astrocytes. This idea provokes numerous questions about cholesterol homeostasis in neurons and glia that need to be addressed by future studies. Given the complexity of cholesterol and lipoprotein metabolism and of neuron-glia interactions, these studies will require new animal models and techniques to manipulate and monitor cholesterol in the brain. These experiments may provide new insight into the still poorly understood cholesterol metabolism in the brain and its involvement in neurodegenerative processes.

\section{Acknowledgments}

I thank D. Dalencon for help with the literature search and J.M. Dietschy, D.H. Holtzman, L. Liscum, M. Muzet and J.E. Vance for valuable comments on the manuscript.

\section{References}

1. Castellano Lopez B, Nieto-Sampedro M. Glial cell function. Progress in Brain Research, Vol. 132. Amsterdam: Elsevier. 2001.

2. Lemke G. Glial control of neuronal development. Annu Rev Neurosci 2001;24:87-105

\section{BioEssays 25.1}


3. Mahley RW. Apolipoprotein E: cholesterol transport protein with expanding role in cell biology. Science 1988;240:622-630.

4. Danik M, Champagne D, Petit-Turcotte C, Beffert U, Poirier J. Brain lipoprotein metabolism and its relation to neurodegenerative disease. Crit Rev Neurobiol 1999;13:357-407.

5. Dietschy JM, Turley SD. Cholesterol metabolism in the brain. Curr Opin Lipidol 2001;12:105-112.

6. Schmitz G, Orso E. Intracellular cholesterol and phospholipid trafficking: comparable mechanisms in macrophages and neuronal cells. Neurochem Res 2001;26:1045-1068.

7. Fagan AM, Holtzman DM. Astrocyte lipoproteins, effects of apoE on neuronal function, and role of apoE in amyloid-beta deposition in vivo. Microsc Res Tech 2000;50:297-304

8. Tsutsui K, Ukena K, Usui M, Sakamoto H, Takase M. Novel brain function: biosynthesis and actions of neurosteroids in neurons. Neurosci Res 2000;36:261-273.

9. Baulieu EE, Robel P, Schumacher M. Neurosteroids: beginning of the story. Int Rev Neurobiol 2001;46:1-32.

10. Pfrieger FW, Barres BA. New views on synapse-glia interactions. Curr Opin Neurobiol 1996;6:615-621.

11. Pfrieger FW, Barres BA. Synaptic efficacy enhanced by glial cells. Science 1997;277:1684-1687.

12. Meyer-Franke A, Kaplan MR, Pfrieger FW, Barres BA. Characterization of the signaling interactions that promote the survival and growth of developing retinal ganglion cells in culture. Neuron 1995;15:805819

13. Nägler K, Mauch DH, Pfrieger FW. Glia-derived signals induce synapse formation in neurones of the rat central nervous system. J Physiol 2001; 533:665-679

14. Ullian EM, Sapperstein SK, Christopherson KS, Barres BA. Control of synapse number by glia. Science 2001;291:657-661.

15. Mauch DH, Nägler K, Schumacher S, Göritz C, Müller EC, Otto A Pfrieger FW. CNS synaptogenesis promoted by glia-derived cholesterol. Science 2001;294:1354-1357.

16. Göritz C, Mauch DH, Nägler K, Pfrieger FW. Role of glia-derived cholesterol in synaptogenesis: new revelations in the synapse-glia affair. J Physiol Paris 2002;96:257-263.

17. Pfrieger FW. Role of cholesterol in synapse formation and function Biochim Biophys Acta 2002; in press.

18. Pfrieger FW. Role of glia in synapse development. Curr Opin Neurobio 2002;12:486-490.

19. Handelmann GE, Boyles JK, Weisgraber KH, Mahley RW, Pitas RE. Effects of apolipoprotein E, beta-very low density lipoproteins, and cholesterol on the extension of neurites by rabbit dorsal root ganglion neurons in vitro. J Lipid Res 1992;33:1677-1688.

20. De Chaves El, Rusinol AE, Vance DE, Campenot RB, Vance JE. Role of lipoproteins in the delivery of lipids to axons during axonal regeneration. J Biol Chem 1997:272:30766-30773.

21. Michikawa M, Yanagisawa K. Inhibition of cholesterol production but not of nonsterol isoprenoid products induces neuronal cell death. J Neurochem 1999;72:2278-2285.

22. Fan QW, Yu W, Senda T, Yanagisawa K, Michikawa M. Cholesteroldependent modulation of tau phosphorylation in cultured neurons. J Neurochem 2001;76:391-400

23. Saito M, Benson EP, Saito M, Rosenberg A. Metabolism of cholestero and triacylglycerol in cultured chick neuronal cells, glial cells, and fibroblasts: accumulation of esterified cholesterol in serum-free culture. J Neurosci Res 1987;18:319-325.

24. Shanmugaratnam J, Berg E, Kimerer L, Johnson RJ, Amaratunga A Schreiber BM, Fine RE. Retinal Muller glia secrete apolipoproteins E and $\mathrm{J}$ which are efficiently assembled into lipoprotein particles. Brain Res Mol Brain Res 1997:50:113-120.

25. LaDu MJ, Gilligan SM, Lukens JR, Cabana VG, Reardon CA, Van Eldik LJ, Holtzman DM. Nascent astrocyte particles differ from lipoproteins in CSF. J Neurochem 1998;70:2070-2081.

26. DeMattos RB, et al. Purification and characterization of astrocytesecreted apolipoprotein $\mathrm{E}$ and J-containing lipoproteins from wild-type and human apoE transgenic mice. Neurochem Int 2001;39:415-425

27. Volpe JJ, Hennessy SW. Cholesterol biosynthesis and 3-hydroxy-3methyl-glutaryl coenzyme $A$ reductase in cultured glial and neuronal cells. Regulation by lipoprotein and by certain free sterols. Biochim Biophys Acta 1977;486:408-420.

28. Langan TJ, limori Y, White G, Volpe JJ. Regulation of sterol synthesis and of 3-hydroxy-3-methylglutaryl coenzyme A reductase by lipoproteins in glial cells in primary culture. J Neurosci Res 1987;17:361-366.

29. Patel SC, Asotra K, Patel YC, McConathy WJ, Patel RC, Suresh S. Astrocytes synthesize and secrete the lipophilic ligand carrier apolipoprotein D. Neuroreport 1995;6:653-657.

30. Kabara JJ. A critical review of brain cholesterol metabolism. Prog Brain Res 1973;40:363-382.

31. Morell $P$, Jurevics $H$. Origin of cholesterol in myelin. Neurochem Res 1996;21:463-470.

32. Lopes-Cardozo M, Larsson OM, Schousboe A. Acetoacetate and glucose as lipid precursors and energy substrates in primary cultures of astrocytes and neurons from mouse cerebral cortex. J Neurochem 1986;46:773-778.

33. Vance JE, Pan D, Campenot RB, Bussiere M, Vance DE. Evidence that the major membrane lipids, except cholesterol, are made in axons of cultured rat sympathetic neurons. J Neurochem 1994;62:329-337.

34. Blaker WD, Toews AD, Morell P. Cholesterol is a component of the rapid phase of axonal transport. J Neurobiol 1980;11:243-250.

35. Runquist M, Parmryd I, Thelin A, Chojnacki T, Dallner G. Distribution of branch point prenyltransferases in regions of bovine brain. J Neurochem 1995;65:2299-2306.

36. Bae SH, Lee JN, Fitzky BU, Seong J, Paik YK. Cholesterol biosynthesis from lanosterol. Molecular cloning, tissue distribution, expression, chromosomal localization, and regulation of rat 7-dehydrocholesterol reductase, a Smith-Lemli-Opitz syndrome-related protein. J Biol Chem 1999;274:14624-14631.

37. Ness GC. Developmental regulation of the expression of genes encoding proteins involved in cholesterol homeostasis. Am J Med Genet 1994; 50:355-357.

38. Hanaka S, Abe T, Itakura H, Matsumoto A. Gene expression related to cholesterol metabolism in mouse brain during development. Brain Dev 2000;22:321-326.

39. Swanson LW, Simmons DM, Hofmann SL, Goldstein JL, Brown MS Localization of mRNA for low density lipoprotein receptor and a cholesterol synthetic enzyme in rabbit nervous system by in situ hybridization. Proc Natl Acad Sci USA 1988;85:9821-9825.

40. Magistretti PJ, Pellerin L. Cellular mechanisms of brain energy metabolism and their relevance to functional brain imaging. Philos Trans $\mathrm{R}$ Soc Lond B Biol Sci 1999;354:1155-1163.

41. Rothman DL, Sibson NR, Hyder F, Shen J, Behar KL, Shulman RG. In vivo nuclear magnetic resonance spectroscopy studies of the relationship between the glutamate-glutamine neurotransmitter cycle and functional neuroenergetics. Philos Trans R Soc Lond B Biol Sci 1999;354: 1165-1177

42. Deitmer JW. Glial strategy for metabolic shuttling and neuronal function Bioessays 2000;22:747-752.

43. Kitano H. Systems biology: a brief overview. Science 2002;295:1662-1664.

44. Brown MS, Goldstein JL. A receptor-mediated pathway for cholesterol homeostasis. Science 1986;232:34-47.

45. Simons K, Ikonen E. How cells handle cholesterol. Science 2000;290: $1721-1726$

46. Beffert U, Danik M, Krzywkowski P, Ramassamy C, Berrada F, Poirier J. The neurobiology of apolipoproteins and their receptors in the CNS and Alzheimer's disease. Brain Res Rev 1998:27:119-142.

47. Herz J, Bock HH. Lipoprotein receptors in the nervous system. Annu Rev Biochem 2002;71:405-434.

48. Brown MD, Banker GA, Hussaini IM, Gonias SL, VandenBerg SR. Low density lipoprotein receptor-related protein is expressed early and becomes restricted to a somatodendritic domain during neuronal differentiation in culture. Brain Res 1997;747:313-317.

49. Stockinger W, Hengstschlager-Ottnad E, Novak S, Matus A, Huttinger H, Bauer J, Lassmann H, Schneider WJ, Nimpf J. The low density lipoprotein receptor gene family. Differential expression of two alpha2macroglobulin receptors in the brain. J Biol Chem 1998;273:3221332221.

50. Parton RG, Simons K, Dotti CG. Axonal and dendritic endocytic pathways in cultured neurons. J Cell Biol 1992;119:123-137. 
51. Ignatius MJ, Shooter EM, Pitas RE, Mahley RW. Lipoprotein uptake by neuronal growth cones in vitro. Science 1987;236:959-962.

52. Zhang Y, Appelkvist EL, Kristensson K, Dallner G. The lipid compositions of different regions of rat brain during development and aging. Neurobiol Aging 1996; 17:869-875

53. Ong WY, Hu CY, Soh YP, Lim TM, Pentchev PG, Patel SC. Neuronal localization of sterol regulatory element binding protein-1 in the rodent and primate brain: a light and electron microscopic immunocytochemical study. Neuroscience 2000;97:143-153.

54. Prasad A, Fischer WA, Maue RA, Henderson LP. Regional and developmental expression of the Npc1 mRNA in the mouse brain. J Neurochem 2000;75:1250-1257.

55. Bu G, Maksymovitch EA, Nerbonne JM, Schwartz AL. Expression and function of the low density lipoprotein receptor-related protein (LRP) in mammalian central neurons. J Biol Chem 1994;269:18521-18528.

56. Brown MS, Goldstein JL. The SREBP pathway: regulation of cholesterol metabolism by proteolysis of a membrane-bound transcription factor. Cell 1997;89:331-340.

57. Brown MS, Goldstein JL. A proteolytic pathway that controls the cholesterol content of membranes, cells, and blood. Proc Natl Acad Sci USA 1999;96:11041-11048.

58. Haydon PG. GLIA: listening and talking to the synapse. Nat Rev Neurosci 2001;2:185-193.

59. Matthies H Jr., Schulz S, Hollt V, Krug M. Inhibition by compactin demonstrates a requirement of isoprenoid metabolism for long-term potentiation in rat hippocampal slices. Neuroscience 1997;79:341346

60. Koudinov AR, Koudinova NV. Essential role for cholesterol in synapticplasticity and neuronal degeneration. FASEB J 2001;15:1858-1860.

61. Geinisman Y, Berry RW, Disterhoft JF, Power JM, Van der Zee EA. Associative learning elicits the formation of multiple-synapse boutons. J Neurosci 2001:21:5568-5573.

62. O'Brien WT, Xu G, Batta A, Tint GS, Salen G, Dyer CA, Kendler A, Servatius RJ. Developmental sensitivity of associative learning to cholesterol synthesis inhibitors. Behav Brain Res 2002;129:141-152.

63. Wellington $\mathrm{CL}$, et al. $\mathrm{ABCA} 1 \mathrm{mRNA}$ and protein distribution patterns predict multiple different roles and levels of regulation. Lab Invest 2002;82:273-283.

64. Bjorkhem I, Diczfalusy U, Lutjohann D. Removal of cholesterol from extrahepatic sources by oxidative mechanisms. Curr Opin Lipidol 1999; 10:161-165.

65. Lund EG, Guileyardo JM, Russell DW. cDNA cloning of cholesterol 24hydroxylase, a mediator of cholesterol homeostasis in the brain. Proc Natl Acad Sci USA 1999;96:7238-7243

66. Whitney KD, et al. Regulation of cholesterol homeostasis by the liver $x$ receptors in the central nervous system. Mol Endocrinol 2002;16:13781385.

67. Moebius FF, Fitzky BU, Glossmann H. Genetic defects in postsqualene cholesterol biosynthesis. Trends Endocrinol Metab 2000;11:106-114.

68. Roux C, Wolf C, Mulliez N, Gaoua W, Cormier V, Chevy F, Citadelle D. Role of cholesterol in embryonic development. Am J Clin Nutr 2000; 71:1270S-1279S.

69. Nwokoro NA, Wassif CA, Porter FD. Genetic disorders of cholesterol biosynthesis in mice and humans. Mol Genet Metab 2001;74:105-119.

70. Masliah E, Mallory M, Veinbergs I, Miller A, Samuel W. Alterations in apolipoprotein E expression during aging and neurodegeneration. Prog Neurobiol 1996;50:493-503.

71. Fagan AM, et al. Unique lipoproteins secreted by primary astrocytes from wild type, apoE $(-/-)$, and human apoE transgenic mice. J Biol Chem 1999;274:30001-30007.

72. Herz J, Clouthier DE, Hammer RE. LDL receptor-related protein internalizes and degrades UPA-PAl-1 complexes and is essential for embryo implantation. Cell 1992;71:411-421.

73. Willnow TE, Hilpert J, Armstrong SA, Rohlmann A, Hammer RE, Burns DK, Herz J. Defective forebrain development in mice lacking gp330/megalin. Proc Natl Acad Sci USA 1996:93:8460-8464.

74. Trommsdorff M, Gotthardt M, Hiesberger T, Shelton J, Stockinger W, Nimpf J, Hammer RE, Richardson JA, Herz J. Reeler/Disabled-like disruption of neuronal migration in knockout mice lacking the VLDL receptor and ApoE receptor 2. Cell 1999;97:689-701.

75. Dietschy JM, Turley SD. Control of cholesterol turnover in the mouse. J Biol Chem 2002;277:3801-3804

76. Waterham HR, Wanders RJ. Biochemical and genetic aspects of 7-dehydrocholesterol reductase and Smith-Lemli-Opitz syndrome. Biochim Biophys Acta 2000;1529:340-356.

77. Selkoe DJ. Alzheimer's disease: genes, proteins, and therapy. Physio Rev 2001:81:741-766.

78. Simons M, Keller P, De Strooper B, Beyreuther K, Dotti CG, Simons K. Cholesterol depletion inhibits the generation of beta-amyloid in hippocampal neurons. Proc Natl Acad Sci USA 1998;95:6460-6464.

79. Chochina SV, Avdulov NA, Igbavboa U, Cleary JP, O'Hare EO, Wood WG. Amyloid beta-peptide1-40 increases neuronal membrane fluidity: role of cholesterol and brain region. J Lipid Res 2001;42:12921297.

80. Michikawa M, Gong JS, Fan QW, Sawamura N, Yanagisawa K. A novel action of alzheimer's amyloid beta-protein (Abeta): oligomeric Abeta promotes lipid release. J Neurosci 2001;21:7226-7235.

81. Runz H, Rietdorf J, Tomic I, de Bernard M, Beyreuther K, Pepperkok R Hartmann T. Inhibition of intracellular cholesterol transport alters presenilin localization and amyloid precursor protein processing in neurona cells. J Neurosci 2002;22:1679-1689.

82. Michikawa M, Fan QW, Isobe I, Yanagisawa K. Apolipoprotein E exhibits isoform-specific promotion of lipid efflux from astrocytes and neurons in culture. J Neurochem 2000;74:1008-1016

83. Wood WG, Schroeder F, Avdulov NA, Chochina SV, Igbavboa U. Recent advances in brain cholesterol dynamics: transport, domains, and Alzheimer's disease. Lipids 1999;34:225-234

84. Lynch C, Mobley W. Comprehensive theory of Alzheimer's disease. The effects of cholesterol on membrane receptor trafficking. Ann NY Acad Sci 2000:924:104-111

85. Poirier J. Apolipoprotein E and Alzheimer's disease. A role in amyloid catabolism. Ann N Y Acad Sci 2000;924:81-90.

86. Hartmann T. Cholesterol, A beta and Alzheimer's disease. Trends Neurosci 2001;24:S45-S48

87. Pentchev PG, Vanier MT, Suzuki K, Patterson MC. Niemann-Pick disease, type C: a cellular cholesterol lipidosis. In: Scriver CR, Beaudet AL, Sly WS, Valle D, editors. The metabolic and molecular bases of inherited disease. New York: McGraw-Hill; 1995. pp 2625-2640.

88. Liscum L. Niemann-Pick type $\mathrm{C}$ mutations cause lipid traffic jam. Traffic 2000;1:218-225

89. Ong WY, Kumar U, Switzer RC, Sidhu A, Suresh G, Hu CY, Patel SC Neurodegeneration in Niemann-Pick type $\mathrm{C}$ disease mice. Exp Brain Res 2001;141:218-231.

90. German DC, Quintero EM, Liang CL, Ng B, Punia S, Xie C, Dietschy JM Selective neurodegeneration, without neurofibrillary tangles, in a mouse model of Niemann-Pick C disease. J Comp Neurol 2001;433:415425.

91. Henderson LP, Lin L, Prasad A, Paul CA, Chang TY, Maue RA Embryonic striatal neurons from niemann-pick type $C$ mice exhibit defects in cholesterol metabolism and neurotrophin responsiveness. J Bio Chem 2000;275:20179-20187.

92. Patel SC, et al. Localization of Niemann-Pick C1 protein in astrocytes: implications for neuronal degeneration in Niemann- Pick type $\mathrm{C}$ disease. Proc Natl Acad Sci USA 1999;96:1657-1662.

93. Patel SC, Asotra K, Patel YC, Patel RC, Suresh S. 25-Hydroxycholestero induces reorganization of lysosomes in normal but not Niemann-Pick disease type C astrocytes. Neuroreport 1994;5:2121-2124.

94. German DC, Liang CL, Song T, Yazdani U, Xie C, Dietschy JM. Neurodegeneration in the Niemann-Pick C mouse: glial involvement. Neuroscience 2002;109:437-450.

95. Suresh S, Yan Z, Patel RC, Patel YC, Patel SC. Cellular cholestero storage in the Niemann-Pick disease type $\mathrm{C}$ mouse is associated with increased expression and defective processing of apolipoprotein D. J Neurochem 1998;70:242-251.

96. Weissleder R, Mahmood U. Molecular imaging. Radiology 2001;219: 316-333.

\section{BioEssays 25.1}

